\title{
CORRECTION
}

\section{Correction to: Hypoalbuminemia and acute kidney injury: a meta-analysis of observational clinical studies}

\author{
Christian J. Wiedermann ${ }^{1 *}$, Wolfgang Wiedermann ${ }^{2}$ and Michael Joannidis ${ }^{3}$
}

(c) 2020 The Author(s)

\section{Correction to: Intensive Care Med (2010) 36:1657-1665 https://doi.org/10.1007/s00134-010-1928-z}

The article Hypoalbuminemia and acute kidney injury: a meta-analysis of observational clinical studies, written by Christian J. Wiedermann, Wolfgang Wiedermann and Michael Joannidis, was originally published Online First without Open Access. After publication in volume 36, page 1657-1665 the author decided to opt for Open Choice and to make the article an Open Access publication. Therefore, the copyright of the article has been changed to $\odot$ The Author(s) 2010 and the article is forthwith distributed under the terms of the Creative Commons Attribution-NonCommercial 4.0 International License, which permits any non-commercial use, sharing, adaptation, distribution and reproduction in any medium or format, as long as you give appropriate credit to the original author(s) and the source, provide a link to the Creative Commons licence, and indicate if changes were made. The images or other third party material in this article are included in the article's Creative Commons licence, unless indicated otherwise in a credit line to the material. If material is not included in the article's Creative Commons licence and your intended use is not permitted by statutory regulation or exceeds the permitted

*Correspondence: christian.wiedermann@asbz.it

${ }^{1}$ Division of Internal Medicine, Central Hospital of Bolzano, Lorenz Böhler

Street 5, 39100 Bolzano, Italy

Full author information is available at the end of the article

The original article can be found online at https://doi.org/10.1007/s0013 4-010-1928-z. use, you will need to obtain permission directly from the copyright holder. To view a copy of this licence, visit https ://creativecommons.org/licenses/by-nc/4.0/. The original version of this article was revised due to a retrospective Open Access order.

\section{Author details \\ ${ }^{1}$ Division of Internal Medicine, Central Hospital of Bolzano, Lorenz Böhler Street 5, 39100 Bolzano, Italy. ${ }^{2}$ Division of Applied Psychology and Research Methodology, Institute of Psychology, University of Klagenfurt, Klagenfurt, Austria. ${ }^{3}$ Department of Internal Medicine I, Medical University of Innsbruck, Innsbruck, Austria.}

\section{Open Access}

This article is licensed under a Creative Commons Attribution-NonCommercial 4.0 International License, which permits any non-commercial use, sharing, adaptation, distribution and reproduction in any medium or format, as long as you give appropriate credit to the original author(s) and the source, provide a link to the Creative Commons licence, and indicate if changes were made. The images or other third party material in this article are included in the article's Creative Commons licence, unless indicated otherwise in a credit line to the material. If material is not included in the article's Creative Commons licence and your intended use is not permitted by statutory regulation or exceeds the permitted use, you will need to obtain permission directly from the copyright holder. To view a copy of this licence, visit http://creativecommons.org/licen ses/by-nc/4.0/.

\section{Publisher's Note}

Springer Nature remains neutral with regard to jurisdictional claims in published maps and institutional affiliations.

Published online: 14 October 2020 